\title{
Physicochemical status of water samples from hand-dug wells in Ajebamidele area of Ado-Ekiti, Southwest, Nigeria
}

\author{
E.A.A. OYEDELE
}

Department of Physics, University of Ado - Ekiti, Nigeria.

Email: akinakin02@yahoo.com

\begin{abstract}
Physicochemical analysis of water samples from hand-dug wells in Ajebamidele area of Ado-Ekiti, Southwest, Nigeria were carried out in order to assess the quality of water from these sources. Samples were taken from 24 evenly distributed wells and 20 parameters were determined. The results showed variations in physicochemical quality of water from the hand-dug wells. A synthesis of the data indicates that most of the well waters are potable since the concentrations of ions in majority of the samples are below the maximum permissible level indicated in the World Health Organization (WHO) standards. Complimentary pre-use treatments would enhance the quality status of the well water as desirable.

() 2009 International Formulae Group. All rights reserved
\end{abstract}

Keywords: Regolith, pollution, potability, wells, parameters.

\section{INTRODUCTION}

The water distribution system in Ado Ekiti, Southwest, Nigeria is grossly inadequate for consumers due to astronomical increase in human population, logistics and leakage. This inevitably undermines the confidence of consumers, resulting to complaints and possibly the use of water from unhygienic sources. Most homes now depend on water from hand - dug wells.

Ajebamidele is a fast growing community in the outskirts of Ado-Ekiti metropolis. It depends on rain water, surface water and groundwater for its water supplies. It is underlain by crystalline rocks of the Basement complex, which is highly weathered, fractured, jointed and faulted. The thickness of the regolith varies greatly. On this, hand-dug wells and boreholes are sunk (Olorunfemi et al., 1999; Rahaman, 1988). Consequently, the groundwater quality status of the area must be ascertained and its contamination made prohibitive.

The threat to the safety and quality of water resources originated from water itself in the form of wastewater. Almost all water used by man turns into wastewater, which requires proper disposal to prevent it from polluting water sources such as rivers, Lakes and groundwater/wells. Pollution of groundwater may also occur due to the contamination potential of leachate from open dumps and sanitary landfills (Badmus et al., 2001). Safe water supply and proper wastewater disposal is one of the preventive measures in controlling groundwater pollution. Water and wastewater are interrelated environmental components that mutually complement each other. Due to this complimentary relationship, water and waste projects must be designed, constructed and maintained simultaneously (Adelusi et al., 2004).

In general, it is cheaper to protect good quality groundwater supplies from contamination than to apply extensive treatment to sources that are already contaminated. Groundwater sources are often of good quality and may only require protection and disinfection in order to provide good quality sources of water for drinking 
(Caincross and Feachem, 1983; Makeig, 1982). Groundwater is significantly protected from surface pollutants as the earth media (composed of different subsurface layers) act as natural filter to infiltrated water. It very rarely needs to be treated before consumption hence cheap to develop (Olorunfemi et al., 1999).

The quantity and quality of water consumption is directly linked to health. Outbreaks of water - transmitted diseases have a major impact on human health. The quality of water is thus, of vital concern for mankind since it is directly linked with human welfare (Adefemi et al., 2007). Pollution of groundwater is indicated by the presence of toxic materials or unwanted materials that may arise from human activities or natural sources (Okoli et al., 2005; Badmus et al., 2001). The central objective of this work is to determine the physico-chemical quality of water from hand-dug wells in the study area. The community is heavily dependent on such wells for various activities. The result of this study would offer a guide on the quality status of the hand-dug wells in the community and create general environmental awareness.

\section{MATERIALS AND METHODS}

Water samples were taken from 24 hand-dug wells with an even spread within the study area using the Grab water sampling technique (Okoli et al., 2005; Badmus et al., 2001). The samples were collected early in the morning between the hours of 6:00 a.m. and 9:00 a.m. into clean and sterilized bottles with stoppers firmly in place. The temperature of each sample and a couple of other parameters were determined immediately at the point of collection. Various standard methods were used for the determination of other parameters in the laboratory (Adefemi et al., 2007).

A total of twenty (20) parameters were determined including colour, odour, temperature, taste, turbidity, conductivity, $\mathrm{pH}$, hardness, total dissolved solids, total suspended solids, chlorides, nitrates, dissolved oxygen, ammonia, magnesium, calcium, Carbonate and Bi-carbonate Alkalinity.

All the data generated were subjected to simple descriptive statistics such as averages, percentages, standard deviations and charts (Karunakaran et al., 2009; Jafari et al., 2008).
The parameters identified were measured against the provisions of the World Health Organization (WHO) standards for potable water.

Any water supply must be judged on its properties as a whole. The acceptability of water is evaluated in terms of the quality requirements for a specific beneficial use (Okoli et al., 2005). In the case of drinking water, temperature and taste are among the important criteria. Factors such as saturation values of solids and gases dissolved in water, Bio-chemical oxygen demand, B.O.D values and the Biological activities are dependent on temperature of water. The suspended solid content, which is judged only partly from the standpoint of turbidity, is also one of the essential properties. Turbidity, a common water quality indicator can influence taste and colour of drinking water. Turbidity is imparted by the colloidal matter present in water which may be clay and loam or microscopic organisms. Good drinking water must not have colour, odour or taste. It must be void of chemical impurities (Adeyeye and Abulude, 2004; Oteze, 1990; Dezuane, 1979 )

\section{RESULTS}

The results obtained are displayed in Tables 1-3. Charts of comparative forms of interrelated parameters are also presented in Figures 1 - 6.

The colour rating of the water samples ranged between 5 and 60 (an average of 15.21 $\pm 13.79 \mathrm{HU}$ ) with average values of $80.95 \pm$ $108.29 \mathrm{mg} / \mathrm{l}$ for Total solids and $28.91 \pm 55.99$ $\mathrm{mg} / \mathrm{l}$ for suspended solids respectively.

The mean value of Temperature of the samples was $27.65 \pm 0.60{ }^{\circ} \mathrm{C}$ with the $\mathrm{pH}$ values averaging $6.51 \pm 1.22$ for the area. The concentrations of Calcium in the wells ranged between 4 and $346 \mathrm{mg} / \mathrm{l}$ with mean value of $63.93 \pm 67.97 \mathrm{mg} / \mathrm{l}$ while values obtained for Magnesium ranged between 9.5 and $140 \mathrm{mg} / \mathrm{l}$ with an average of $58.40 \pm 29.98 \mathrm{mg} / \mathrm{l}$. Total Hardness in the samples varied from $20-420$ $\mathrm{mg} / \mathrm{l}$ with a mean value of $124.58 \pm 85.77$ $\mathrm{mg} / \mathrm{l}$.

Chlorides concentrations in the wells ranged between 4.5 and $480 \mathrm{mg} / \mathrm{l}$ with mean value of $92.35 \pm 104.81 \mathrm{mg} / \mathrm{l}$ while the 
Table 1: Physicochemical analysis of Ajebamidele hand - dug wells.

\begin{tabular}{|c|c|c|c|c|c|c|c|}
\hline Well No. & Appearance & Odour & Taste & $\begin{array}{l}\text { Colour } \\
\text { (HU) }\end{array}$ & $\begin{array}{l}\text { Turbidity } \\
\text { (NTU) }\end{array}$ & $\begin{array}{l}\text { Total } \\
\text { Solid(mg/l) }\end{array}$ & $\begin{array}{l}\text { Uspended } \\
\text { Solid } \\
(\mathrm{mg} / \mathrm{l})\end{array}$ \\
\hline 1 & Not clear & Odourless & Tasteless & 5 & 1.02 & 3.5 & \\
\hline 2 & Not clean & Objectionable & Bitter & 10 & 8.5 & 12 & $\begin{array}{l}0 \\
6\end{array}$ \\
\hline 3 & Clean, clear & Odourless & Tasteless & 20 & 5.58 & 25 & 0.75 \\
\hline 4 & Sparkling & Odourless & Tasteless & 5 & 18.55 & 90 & 4.9 \\
\hline 5 & Not clear & Objectionable & Muddy & 60 & 105.5 & 420 & 160 \\
\hline 6 & Clean & Odourless & Tasteless & 5 & 5.7 & 5.5 & 2.5 \\
\hline 7 & Clean & Odourless & Tasteless & 5 & 1.05 & 4.7 & 0 \\
\hline 8 & Clear & Objectionable & Bitter & 5 & 12.05 & 4.9 & 2 \\
\hline 9 & Clean, clear & Odourless & Tasteless & 5 & 1 & 2.7 & 0 \\
\hline 10 & Dark & Odourless & Very hard & 15 & 35.7 & 25 & 9 \\
\hline 11 & Brownish & Objectionable & Decay & 10 & 55 & 32 & 200 \\
\hline 12 & Dark & Objectionable & Sewage & 40 & 30.7 & 185 & 90 \\
\hline 13 & Sparkling & Odourless & Tasteless & 40 & 24.75 & 14.8 & 5 \\
\hline 14 & Clear & Odourless & Tasteless & 5 & 25.5 & 9 & 1.5 \\
\hline 15 & Clear & Odourless & Hard & 10 & 21.7 & 41 & $\begin{array}{l}1 \\
2\end{array}$ \\
\hline 16 & Dark & Objectionable & Very hard & 15 & 35.7 & 25 & 9 \\
\hline 17 & Not clear & Objectionable & Rotten & 5 & 29.1 & 100 & 2 \\
\hline 18 & Brownish & Odourless & Tasteless & 5 & 25.5 & 145 & 8.8 \\
\hline 19 & Sparkling & Odourless & Tastless & 20 & 18.55 & 90 & 4.9 \\
\hline 20 & Clean, clear & Odourless & Tasteless & 15 & 5.58 & 25 & 0.75 \\
\hline 21 & Clean, clear & Odourless & Chlorious & 15 & 4 & 55 & 0.25 \\
\hline 22 & Not clear & Odourless & Tasteless & 20 & 5.5 & 61.7 & 27.5 \\
\hline 23 & Not clean & Objectionable & Very hard & 10 & 30 & 230 & $\begin{array}{l}1 \\
3 \\
0\end{array}$ \\
\hline 24 & Not clear & Odourless & Slightly hard & 20 & 12.05 & 48 & 17 \\
\hline $\operatorname{Max}$ & & & & 60 & 105.5 & 420 & 200 \\
\hline Min & & & & 5 & 1 & 2.7 & 0 \\
\hline Mean & & & & 15.21 & 21.60 & 80.95 & 28.91 \\
\hline SD & & & & 13.79 & 22.63 & 108.29 & 55.99 \\
\hline
\end{tabular}


Table 2: Physicochemical analysis of Ajebamidele hand - dug wells.

\begin{tabular}{|c|c|c|c|c|c|c|}
\hline $\begin{array}{l}\text { Well } \\
\text { No. }\end{array}$ & pH & $\begin{array}{l}\text { Temperature } \\
\left({ }^{\circ} \mathrm{C}\right)\end{array}$ & $\begin{array}{l}\text { Electrical } \\
\text { Coductivity }\end{array}$ & $\begin{array}{l}\text { Calcium } \\
(\mathrm{mg} / \mathrm{l})\end{array}$ & $\begin{array}{l}\text { Magnasium } \\
(\mathrm{mg} / \mathrm{l})\end{array}$ & $\begin{array}{l}\text { Total Hardness } \\
(\mathrm{mg} / \mathrm{l})\end{array}$ \\
\hline 1 & 6.8 & 27.1 & 18.6 & 40 & 135 & 100 \\
\hline 2 & 3.5 & 28 & 7.91 & 346 & 56 & 420 \\
\hline 3 & 7.8 & 29 & 5.02 & 45 & 61.5 & 100 \\
\hline 4 & 6.5 & 27.5 & 15.5 & 92 & 40 & 20 \\
\hline 5 & 5.8 & 27.2 & 33.05 & 14.14 & 9.5 & 140 \\
\hline 6 & 7.2 & 29 & 4.5 & 10 & 21 & 80 \\
\hline 7 & 6 & 27.6 & 7.75 & 4 & 76.3 & 70 \\
\hline 8 & 7.5 & 27.6 & 7.85 & 45 & 40 & 140 \\
\hline 9 & 7.8 & 28 & 8.5 & 5.6 & 43.5 & 180 \\
\hline 10 & 5.8 & 27 & 5.75 & 42 & 70 & 40 \\
\hline 11 & 7.5 & 27.4 & 25.75 & 146 & 88 & 100 \\
\hline 12 & 8.2 & 27.6 & 15.5 & 98.5 & 140 & 200 \\
\hline 13 & 6.5 & 27.8 & 20.4 & 56 & 27 & 160 \\
\hline 14 & 7.5 & 27 & 18.2 & 42 & 40.5 & 100 \\
\hline 15 & 6.2 & 27.8 & 11.5 & 70 & 55 & 80 \\
\hline 16 & 5.8 & 27.4 & 5.75 & 42 & 70 & 7 \\
\hline 17 & 7 & 27.6 & 16.5 & 60 & 45 & 200 \\
\hline 18 & 5.5 & 27.8 & 20.55 & 40 & 60 & 180 \\
\hline 19 & 6.5 & 27.5 & 15.5 & 92 & 40 & 20 \\
\hline 20 & 7.8 & 29 & 5.02 & 45 & 61.5 & 100 \\
\hline 21 & 7.2 & 27.3 & 5 & 40 & 50 & 80 \\
\hline 22 & 5.5 & 27 & 4.9 & 55 & 60 & 100 \\
\hline 23 & 6.8 & 27.5 & 7.55 & 59 & 60.5 & 100 \\
\hline 24 & 6.8 & 27.5 & 7.55 & 59 & 60.5 & 100 \\
\hline Max & 8.2 & 29 & 33.05 & 346 & 140 & 420 \\
\hline Min & 3.5 & 27 & 4.5 & 4 & 9.5 & 20 \\
\hline Mean & 6.51 & 27.65 & 12.98 & 63.93 & 58.40 & 124.58 \\
\hline $\mathrm{SD}$ & 1.22 & 0.60 & 8.01 & 67.97 & 29.98 & 85.77 \\
\hline
\end{tabular}

concentrations of nitrates were quite minimal; the mean value being $2.46 \pm 8.12$. The Ammonia values of the well samples are generally low $(0.01-2.00)$ with an average of $0.63 \pm 0.53$. Carbonate and Bi-carbonate Alkalinity values in almost all the well samples were low with $7.60 \pm 12.37$ and 98.22 \pm 74.21 as the mean values respectively.

\section{DISCUSSION}

High values of colour rating recorded in wells 5, 11 and 23 were in consonance with the high values of turbidity exhibited by these samples (Figure 1). The very high value of turbidity in well sample 5 might be due to high sediment discharge from run - off. All the sampled wells have their values for colour lying within the WHO recommended belt except for well sample 5 with the value of 60 . Colour in water is attributable to materials in solution (Karunakaran et al., 2009; Adeyeye and Abulude, 2004; Ojelabi, 2001). Affected wells can be treated by Coagulation, Activated carbon and Chlorination. 67\% of the samples are odourless with similar patterns displayed in taste and appearance. Taste and odour are of prime importance in assessing the palatability of water (Dezuane, 1979).

Figure 2 shows that most of the sampled wells are within the WHO limit for $\mathrm{pH}$ values except wells 2, 18, 22 and 23 
Table 3: Physicochemical analysis of Ajebamidele hand - dug wells.

\begin{tabular}{llllllll}
\hline $\begin{array}{l}\text { Well } \\
\text { No. }\end{array}$ & Ammonia & $\begin{array}{c}\text { Nitrate } \\
(\mathbf{m g} / \mathbf{l})\end{array}$ & $\begin{array}{c}\text { Chloride } \\
(\mathbf{m g} / \mathbf{l})\end{array}$ & $\begin{array}{c}\text { Dissolved } \\
\text { Oxygen(ppm) }\end{array}$ & $\begin{array}{l}\text { Acidity } \\
(\mathbf{m g} / \mathbf{l})\end{array}$ & $\begin{array}{l}\text { Carbonate } \\
\text { Alkalinity }\end{array}$ & $\begin{array}{c}\text { Bi-Carbonate } \\
\text { Alkalinity }\end{array}$ \\
\hline 1 & 1 & 0 & 80 & 5 & 1.5 & 0 & 97.6 \\
2 & 1.5 & 0.5 & 480 & 4.05 & 2.5 & 0 & 245 \\
3 & 0.1 & 0.15 & 12 & 6.75 & 0.2 & 0 & 45 \\
4 & 0.75 & 1 & 100 & 4.93 & 1.5 & 1.2 & 60 \\
5 & 0.6 & 0.15 & 132 & 4.87 & 2 & 15 & 160 \\
6 & 0.1 & 0.15 & 4.5 & 8 & 1 & 0 & 30 \\
7 & 0.1 & 1 & 75 & 4.5 & 0.3 & 0 & 35 \\
8 & 0.01 & 1 & 24 & 11.76 & 0.2 & 40 & 60 \\
9 & 0.1 & 1 & 85 & 60 & 0.3 & 0 & 122 \\
10 & 1 & 1.5 & 32 & 4.84 & 0.1 & 10 & 69 \\
11 & 2 & 40.5 & 75.9 & 4.96 & 0.5 & 0 & 70.15 \\
12 & 1 & 0.3 & 142 & 4.58 & 1.5 & 0 & 75 \\
13 & 1 & 0.3 & 142 & 4.58 & 1.5 & 0 & 75 \\
14 & 0.75 & 0.3 & 10.9 & 4.84 & 0.5 & 0 & 45 \\
15 & 1 & 1 & 100 & 4.65 & 0.2 & 25 & 75 \\
16 & 1 & 1.5 & 32 & 4.84 & 0.1 & 10 & 69 \\
17 & 1 & 1 & 175 & 4.78 & 2 & 25 & 150 \\
18 & 0.75 & 1.5 & 190 & 11.65 & 1.5 & 35 & 255 \\
19 & 0.75 & 1 & 100 & 4.93 & 1.5 & 1.2 & 60 \\
20 & 0.1 & 0.15 & 12 & 6.75 & 0.2 & 0 & 45 \\
21 & 0 & 1 & 60 & 4.6 & 0.2 & 0 & 35 \\
22 & 0.3 & 1.6 & 25 & 4.89 & 0.5 & 0 & 40 \\
23 & 0.15 & 0.3 & 15 & 4.35 & 1 & 0 & 266 \\
24 & 1 & 1.5 & 9.15 & 5 & 0.4 & 20.1 & 48.5 \\
Max & 2 & 40.5 & 480 & 60 & 2.5 & 20.1 & 266 \\
Min & 0.01 & 0 & 4.5 & 4.35 & 0.2 & 0 & 30 \\
Mean & 0.64 & 2.46 & 92.35 & 7.93 & 0.90 & 7.60 & 98.22 \\
SD & 0.53 & 8.12 & 104.81 & 11.28 & 0.76 & 12.37 & 74.21 \\
\hline
\end{tabular}

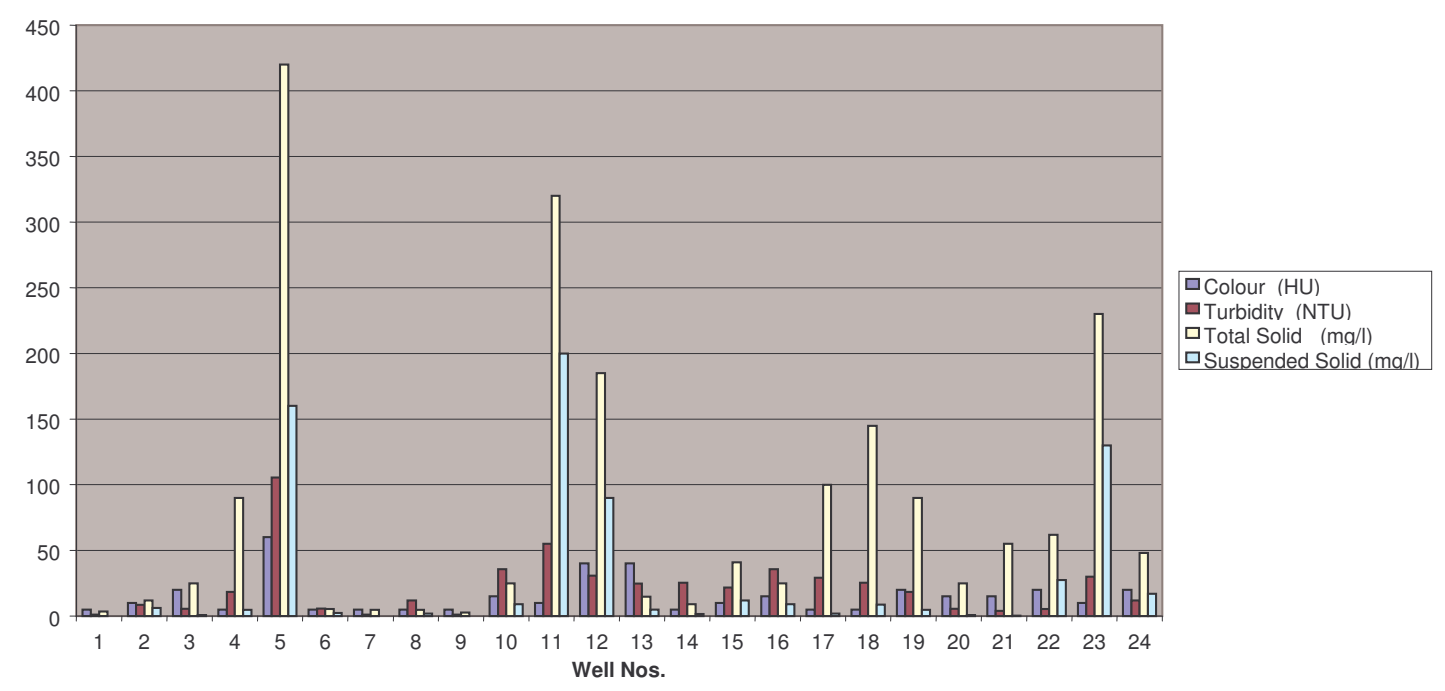

Figure 1: Physicochemical analysis of Ajebamidele hand-dug wells. 


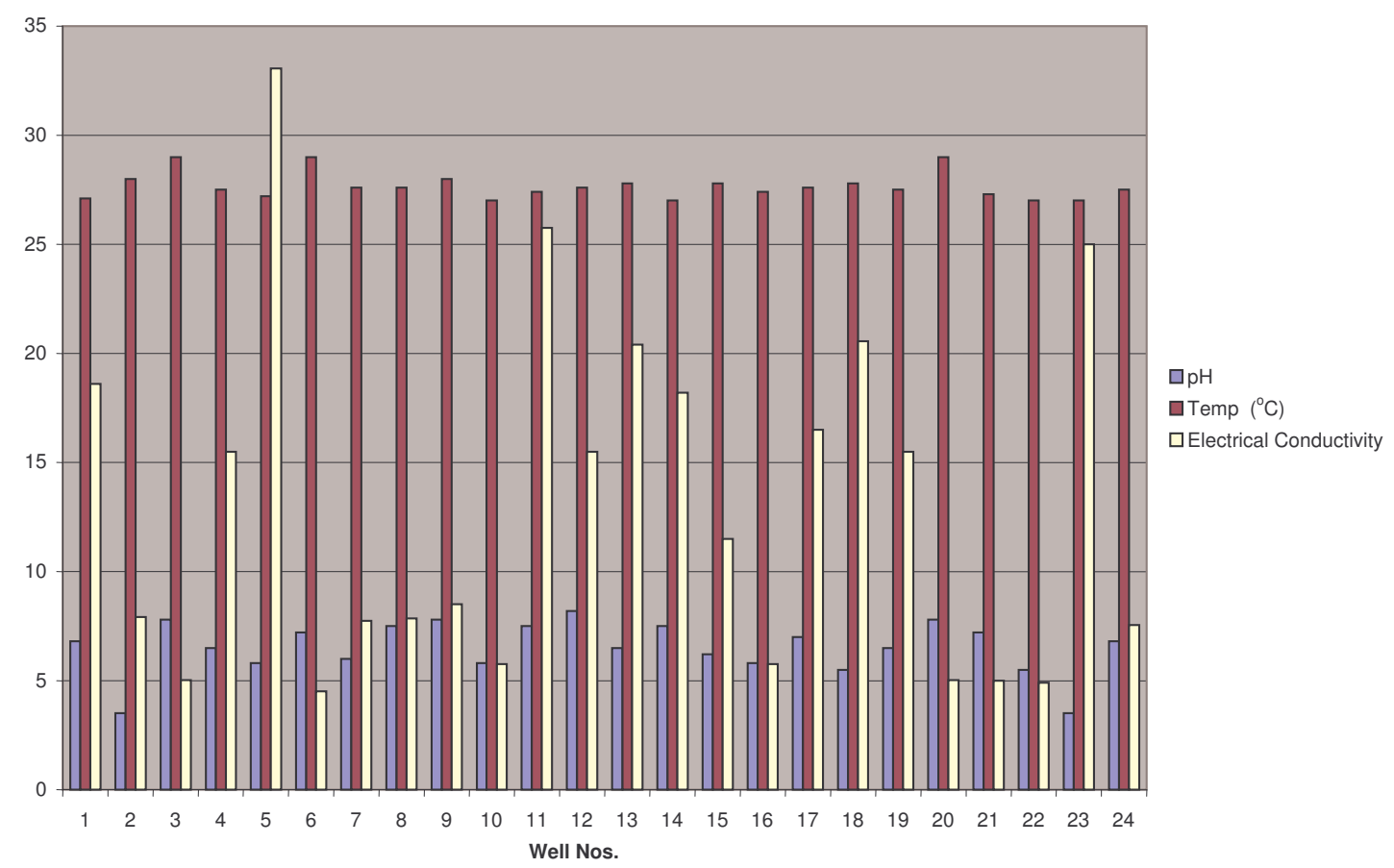

Figure 2: Physicochemical analysis of Ajebamidele hand-dug wells.

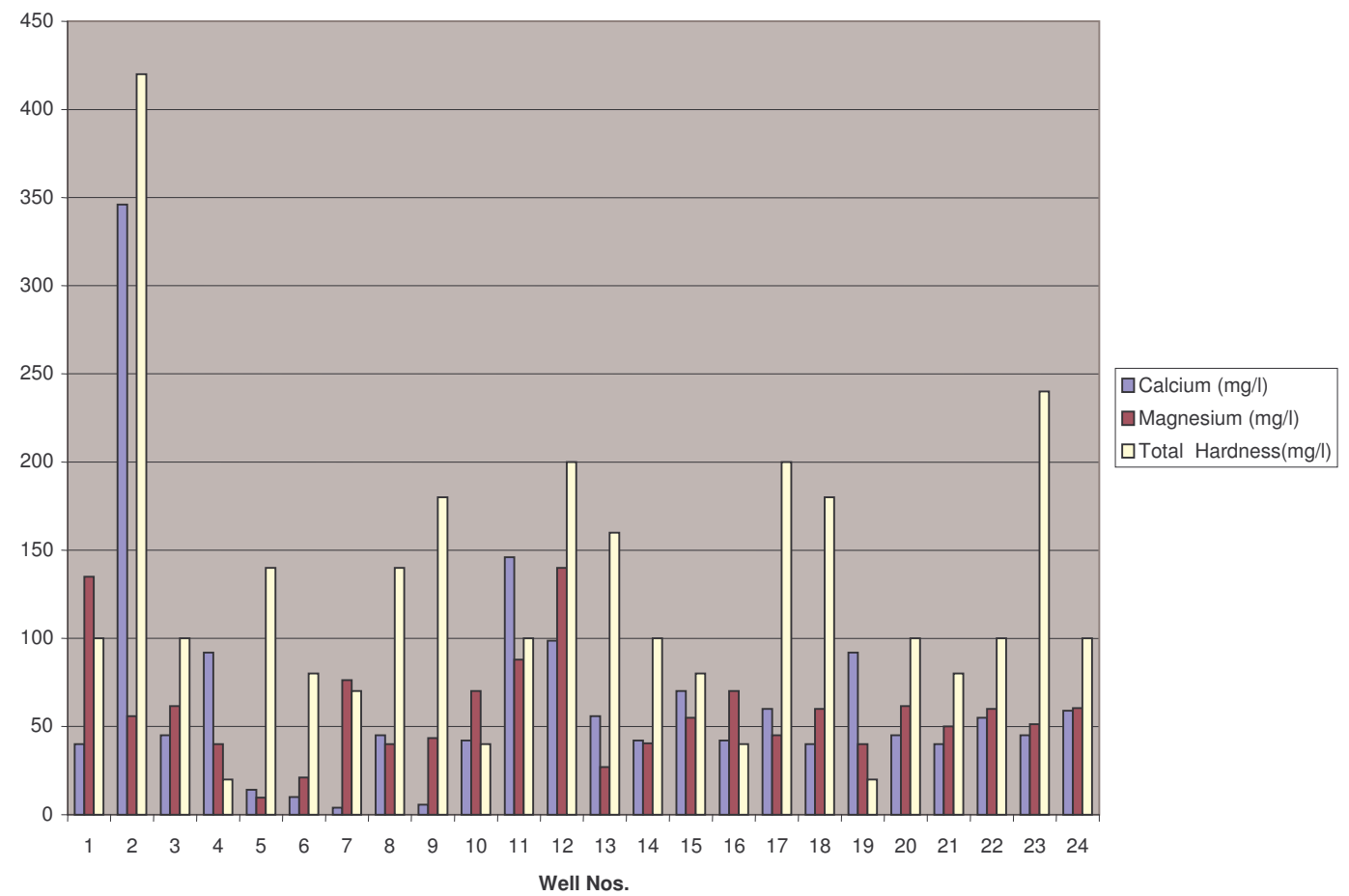

Figure 3: Physicochemical analysis of Ajebamidele hand-dug wells. 


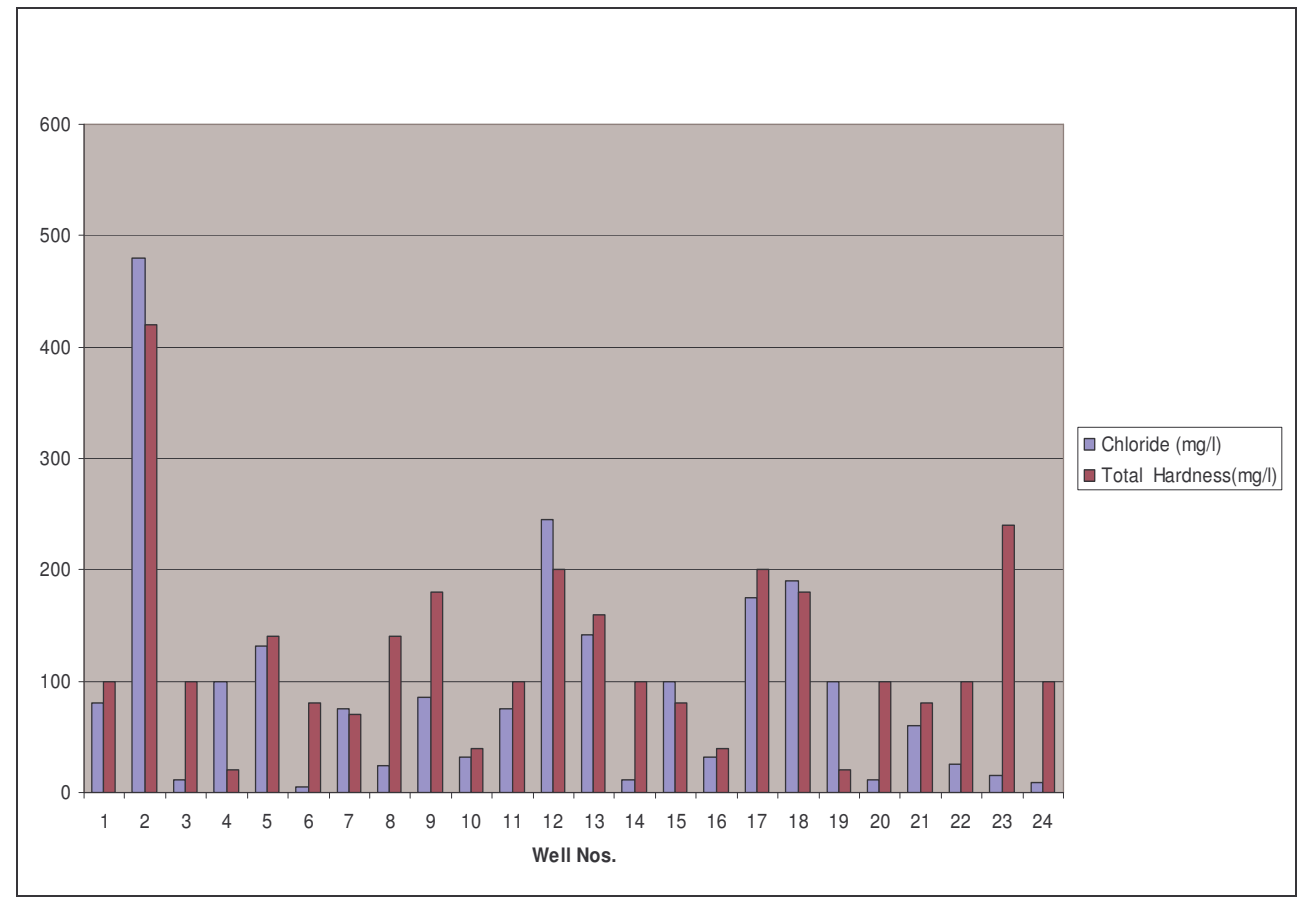

Figure 4: Physicochemical analysis of Ajebamidele hand-dug wells.

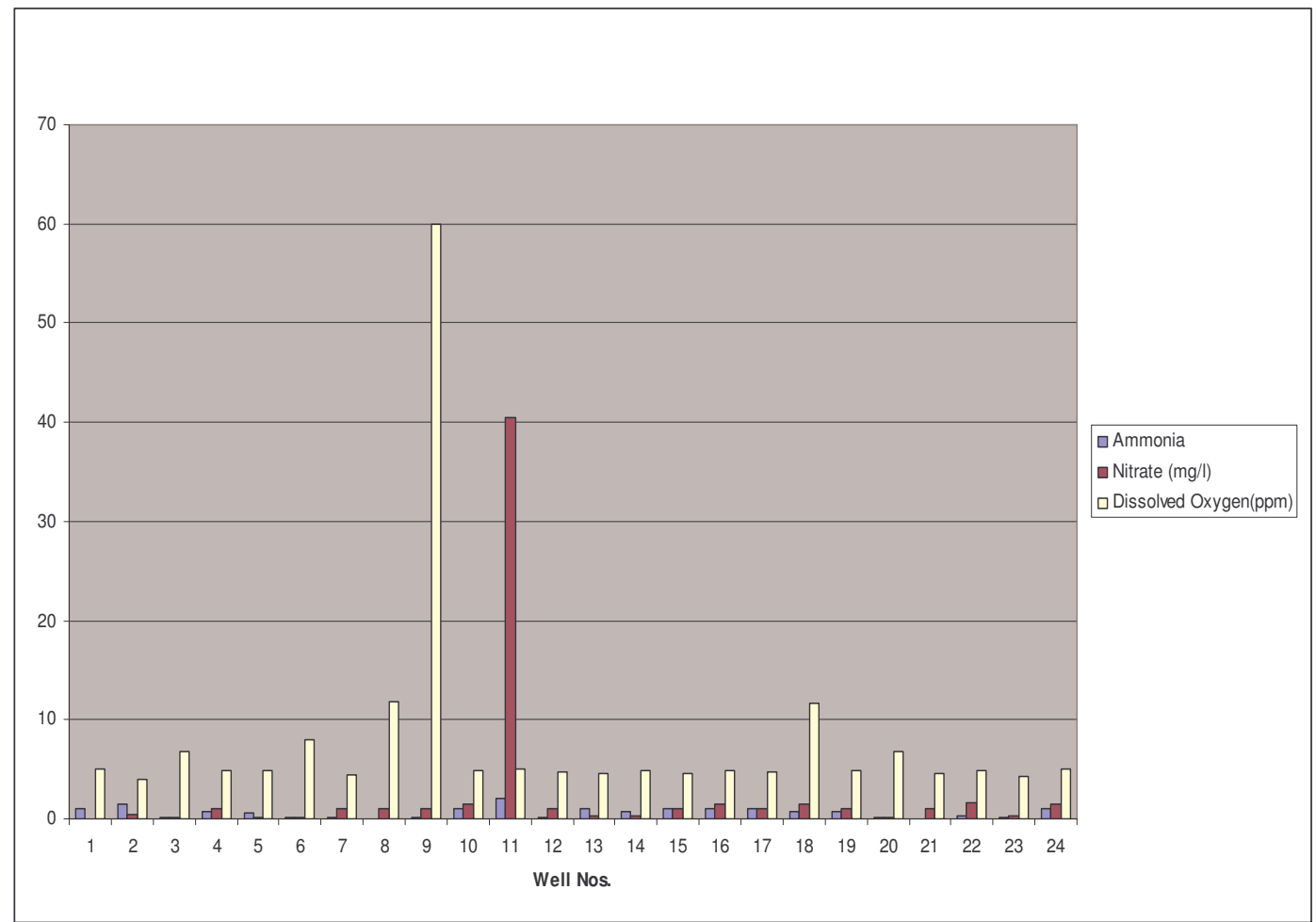

Figure 5: Physicochemical analysis of Ajebamidele hand-dug wells. 


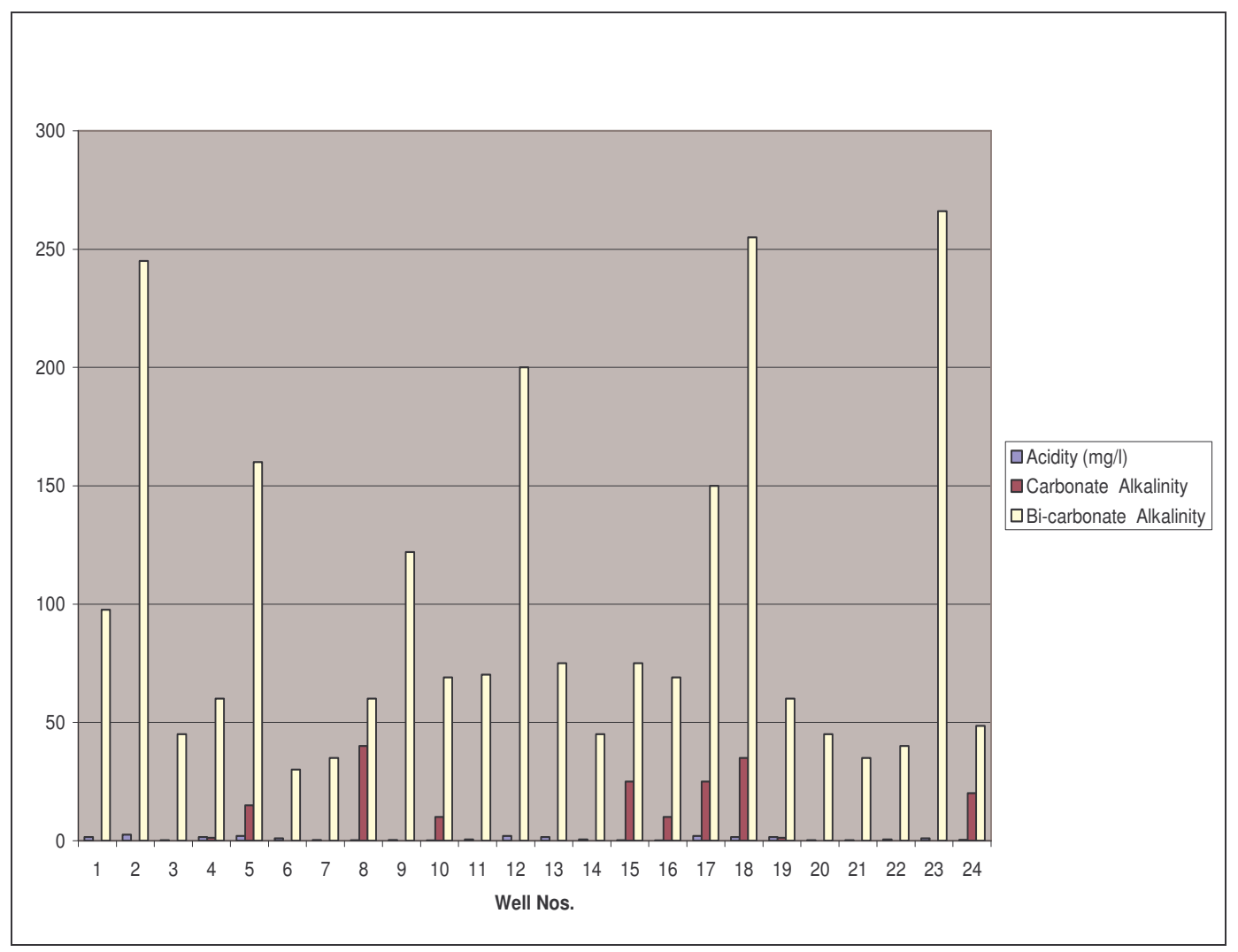

Figure 6 : Physicochemical analysis of Ajebamidele hand-dug wells.

which are slightly acidic. Similar values, a range of 5.90 to 7.60 , were obtained by (Adeyeye and Abulude, 2004) in the analytical assessment of some surface and groundwater resources in Ile-Ife, Nigeria. Preuse treatment by adding lime is required for affected wells.

Calcium and magnesium are the prime constituents concerned with hardness. Total hardness, made up of temporary hardness and permanent hardness, is due to the presence of certain dissolved salts, such as carbonates, bicarbonates, chlorides and sulphates, of calcium and magnesium. Calcium and magnesium are the prime constituents concerned with hardness (Figures 3 and 4).While temporary hardness could be removed by boiling water and by adding lime to water, permanent hardness requires special methods of water softening. Excessive hardness is objectionable as a great deal of soap is required for washing. Formation of scales in boilers/heating systems, corrosion and incrustation of pipelines and plumbing fissures are also promoted (Caincross and Feachem, 1983). Average Total Hardness of $124.58 \pm 85.77 \mathrm{mg} / \mathrm{l}$ observed in the area is within the tolerable limit of the WHO standards except Well 02.

Natural nitrate levels in groundwater are generally very low (typically less than 10 $\mathrm{mg} / \mathrm{l} \mathrm{NO}_{3}$ ), but nitrate concentrations grow due to human activities, such as agriculture, industry, domestic effluents and emissions from combustion engines (Ojelabi, 2001; Makeig, 1982). The ammonia values of the well samples are generally low. The bicarbonate alkalinity values are however noticeably high in well samples 2, 18 and 23 (Figure 6).

The concentrations of ions in majority of the samples are below the maximum 
permissible level indicated in the World Health Organization (WHO) standards. Simple treatment involving the addition of chlorine, alum and perhaps boiling and filtration should be encouraged among the residents as harmful bacterial could be removed by boiling and/or by adding water treating chemicals (Shitta and Oyedele, 2007). In locating a well in future, a geophysical survey should be carried out so as to decipher the subsurface overburden thickness, structural dispositions and the most probable aquiferous zone. This is necessary because the level of contamination of hand-dug wells might not only be related to the depth of the well but also the fracture intensity (Oyedele et al., 2005).

Water pollution control must be recognized as an integral part of water resources management and given due consideration along with irrigation, flood protection and water supply in national water planning as lack of concern for water pollution control may lead to adverse aesthetic and health consequences. There is an urgent need in most developing countries to manage water as a natural resource both in terms of quantity and quality for the benefit of society rather than the individual.

\section{Conclusion}

Most of the well waters are potable since the concentrations of ions in majority of the samples are below the maximum permissible level indicated in the World Health Organization (WHO) standards. Indiscriminate siting of refuse dumps and other waste disposal facilities should be discouraged in the area to avoid the unpleasant consequences of polluting the near surface/shallow hand-dug wells.

\section{ACKNOWLEDGMENTS}

We sincerely appreciate everyone who has contributed in one form or another to the execution of this work especially Mr Makinde of the Water Laboratory, Civil Engineering Department, Federal Polytechnic, Ado Ekiti.

\section{REFERENCES}

Adefemi OS, Asaolu SS, Olaofe O. 2007. Assessment of Physico-Chemical Status of Water Samples from Major Dams in Ekiti State, Nigeria. Parkistan Journal of Nutrition, 6(6): 657-659.

Adelusi AO, Ayuk MA, Oyedele AA. 2004. Hydrogeophysical Analysis of Owode Area around Oba-Ile near Akure, SW Nigeria. African Journal of Development Studies, 4(1\& 2): 11 - 14 .

Adeyeye EI, Abulude EO. 2004. Analytical Assessment of some surface and groundwater resources in Ile-Ife, Nigeria. J. Chemical. Soc. Nigeria, 98-103.

Badmus BS, Oyedele T, Ojelabi EA. 2001. Electrical Resistivity Soundings to determine Subsurface Contamination in the vicinity of Refuse Dump. Global Journal of Pure and Applied Sciences, 7(1): 127-132.

Caincross S, Feachem RG. 1983. Environmental Health Engineering in the Tropics - an Introduction Text $\left(1^{\text {st }}\right.$ edn $)$. John Willey and Sons: NY; 283p.

Dezuane J. 1979. Handbook of Drinking Water Quality. Indiana University Press; $3-17$.

Jafari A, Mirhossaini H, Kamareii B, Debestani S. 2008. Physicochemical analysis of drinking water in Kohdasht City Lorestan, Iran. Asian Journal of Applied Sciences, 1(1): 87-92.

Karunakaran K, Thamilarasu P, Sharmila R. 2009. Statistical study on physicochemical characteristics of groundwater in and around Namakkal, Tamilnadu, India. E-Journal of Chemistry, 6(3): 909-914.

Makeig KS (1982). Natural buffers for sludge leachate stabilization. Groundwater, 20(4): 420 - 429.

Ojelabi EA. 2001.Geographical and chemical analysis of groundwater samples in AgoIwoye area, Southwest, Nigeria. African Journal of Environmental Studies, 2: 7780.

Okoli G, Chidi IV, Njoku N, ACChukwuocha N, Njoku PC, Njoku JD, 
Dike MU, Ojiegbe RU. 2005. Quality characteristics of groundwater utilized by resident students of a Nigerian University. Journal of Applied Sciences, 5(6): 1088-1091.

Olorunfemi MO, Ojo JS, Akintunde OM. 1999. Hydro-geophysical Evaluation of the Groundwater Potentials of the Akure Metropolis, Southwestern Nigeria. Journal of Mining and Geology, 35(2): $207-228$.

Oteze GE. 1990. Trace elements in the groundwater in the Sokoto Basin, Nigeria. Journal of the Nigerian Association of Hydrogeologists, 2(1): 713.

Oyedele AA, Adelusi AO, Oyedele T. 2005. Determination of Aquifer Units using Vertical Electrical Sounding Technique: a case study of Federal Low-cost Housing
Estate Okeho, SW, Nigeria. The Nigerian Journal of Pure \& Applied Physics, 4: 6067.

Rahaman MA. 1988. Recent advances in the study of the basement complex of Nigeria. In Precambrian Geology of Nigeria. Geological Survey of Nigeria, Kaduna South, $11-43$.

Shitta MBO, Oyedele EAA. 2006. Production of water filters using local raw materials. Journal of Biological and Physical Sciences, 4: 94 - 99.

WHO. 1999. Guideline for Drinking Water Quality. 2(1) Recommendation. WHO: Geneva; 30 - 113. 